\title{
European Parliamentary Elections Act 1999: the constitutional issues
}

\author{
by Gabriele Ganz
}

\begin{abstract}
In this article, Professor Gabriele Ganz of Southampton University writes about the passage through Parliament of the Bill preceding the European Parliamentary Elections Act 1999, which received Royal Assent on 14 January 1999, and argues that it raises two fundamental constitutional issues: first, the voting system chosen for elections to the European Parliament and, secondly, the role played by the House of Lords on the eve of the reform of its composition.
\end{abstract}

$\mathrm{T}$ he European Parliamentary Elections Act 1999 ('the Act')is only the second one to become law under the Parliament Act 1949. Unlike its predecessor, the War Crimes Act 1991, the Bill was foreshadowed in the Labour Party manifesto of 1997, although not the precise voting system. It was not, however, fought on purely party political lines. There was considerable opposition within the Labour ranks in the House of Commons and, though the votes in the House of Lords could not have been won without the support of hereditary peers, they also could not have been won without cross-party support and help from the cross-benches. Earl Russell, a Liberal Democrat peer, said, 'It is not a representation of the people Bill; it is a representation of the parties Bill', and it was claimed that the unclected peers were protecting the power of the electorate. Nevertheless, the unprecedented confrontation between the House of Commons and the House of Lords, culminating in the use of the Parliament Acts had zero effect. The government got the Bill passed intact in time to prepare for the European parliamentary elections in June 1999. The Act thus provides a textbook illustration of the dominance of the Executive over the Legislature. Whether a reformed House of Lords would have led to a different result is an open question.

\section{CLOSED LIST SYSTEM}

The story starts with the Labour manifesto of 1997, which stated:

'We have long supported a proportional voting system for election to the European Parliament.

The brevity of this promise, which did not mention a specific voting system, was to play an important part in the confrontation with the House of Lords. Interestingly, the Bill was not included in the Queen's Speech but was brought forward following persuasion by the Liberal Democrats.

Trouble started before the Bill was even published, in October 1997, over a code of conduct gagging Labour MEPs from discussing publicly the new selection procedure for MEPs. Criticism by the opposition parties as well as rebel Labour MEPs greeted publication of the Bill, which provided for the 'closed list' system of proportional representation. The country is divided into electoral regions (nine in England, and one each for Scotland, Wales and Northern Ireland, s. 1 substituting s. 2 of the European Parliamentary Elections Act 1978) and the number of seats allocated for each region is laid down in the Bill (i.e. 71 for England, 8 for Scotland, 5 for Wales and 3 for Northern Ireland, new s. 2(4); Sch. 1 sets out the number of seats allocated for each English region). The voter in each region can vote either for a registered party or for an independent candidate. However, the seats allocated to a party are filled from the party's list in the order in which they appear on the list. In other words, the voter cannot show a preference for any candidate on the list, but only vote for a party, not an individual, unless they are standing as an independent. This raises the fundamental issue of what elections are for.

Although the basic division of opinion between those who support 'first past the post' in preference to proportional representation formed an undercurrent in the debates, as some of the protagonists openly declared, it was conceded by the opposition that proportional representation was a manifesto commitment and had to be accepted as such, particularly in the House of Lords. The Liberal Democrats, in principle, supported a different system of proportional representation, namely the single transferable vote, but did not think it was appropriate in the circumstances of these elections. The debate was thus narrowly focused on whether the system should be one of open or closed party lists. In the former the voters can choose the candidate they prefer from the list, while in the latter the order is determined by the party (a system used by the majority of European voters). The higher a candidate's position on the list, the better are his or her chances of election.

The government argued that closed lists would give a better chance of election to women and ethnic minority candidates, 
and those with a particular expertise, and that voters would not have much knowledge about individual candidates in constituencies the size of regions as envisaged in the Bill. It was also reiterated that a candidate in an open list system could be elected with fewer votes than a candidate who was not elected. This would only have been true as between candidates on the list of different parties, not of candidates on the same party list, under the open list system proposed in the opposition amendment, which was successful in the House of Lords. Under this amendment the voter would vote for an individual candidate on a party list, or an independent candidate, and the total vote for all the candidates of each party would determine the vote for that party and thus the number of seats, which would be allocated in accordance with the number of votes each candidate received.

The argument in favour of giving the voter a choice of candidate is the classic argument of accountability. As Earl Russell put it, perhaps too simplistically:

'All members of elected assemblies ... will try to please those from whom their title to sit comes.'

Open lists would enable the voter to get rid of unpopular candidates and, conversely, to decide between different candidates on the basis of moral and ethical questions such as capital punishment. However, this argument begs the question of whether MPs' primary loyalty is now to their party rather than to their constituents or their consciences. Without doubt, the closed list system tightens the grip of party loyalty.

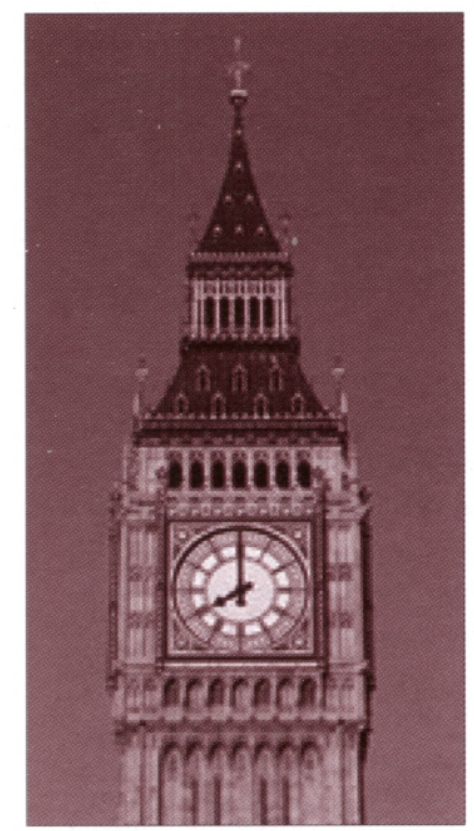

This grip is tightened even more depending on the way in which the party lists are compiled. This is not dealt with in the Bill but is left to the political parties to decide. It was, however, very germane to, and much canvassed in the debates on, open or closed lists. We have already referred to the problems of Labour MEPs opposed to the new selection procedure. Each party has adopted different procedures for compiling its party lists. The crucial issues are who in the party decides whether candidates get onto the lists and the order in which they

appear on the lists. The Liberal Democrats and Conservatives allow party members to determine the order of candidates on the lists, subject in the case of the Conservatives to prior vetting by a panel of local party chairmen. Labour adopted a complicated procedure which involved a ballot of party members at the first stage, but left the crucial decision of who should go on the final lists and the order in which they are listed to a panel consisting of members and nominees of the National Executive Committee and regional representatives of the party. This puts enormous power into the hands of the party leadership over who will be elected and this will strengthen their party loyalty rather than their independence.
During the second reading debate in the Housc of Commons in November 1997, the Home Secretary, Jack Straw, under pressure from the Liberal Democrats and the constitutional reform group Charter 88, agreed to give further consideration to the open list system used in Belgium. He placed an explanatory paper in the library of the Commons and commissioned research from NOP. Though it was soon rumoured that the closed list would remain, Mr Straw did not announce his rejection of the Belgian system until a late stage of the Bill, in March 1998. At the report stage he gave in detail the reason why the Belgian system should be opposed (namely, that under the Belgian system where the voter can vote either for the party or an individual on the list, it is possible for a candidate who is higher on the list to be elected with fewer votes than someone lower down because of the way the quota is allocated).

\section{ROLE OF THE HOUSE OF LORDS}

When the Bill was debated for the first time in the House of Lords, in April 1998, there was much opposition across the political spectrum to the closed list system. This was a foretaste of things to come. Strangely, the confrontation between the two houses took another six months to materialise. Although a Conservative amendment proposing the open list system, which was finally successful in the House of Lords, was first put forward in June 1998, it was not put to the vote because it was getting late. At report stage it was moved again but not put to the vote, on the grounds that it would not have received enough support. It was not until the third reading on 20 October 1998 that the amendment was passed for the first time by a majority of 25. This vote began the game of ping-pong which sent the Bill back and forth between the two Houses for an unprecedented five times. Was this 'a wholly improper abuse of power' by the House of Lords, which was only made possible by enlisting the aid of hereditary peers, or were the unelected peers acting as a bulwark of democracy by using the powers given to them by the Parliament Acts? The truth lies somewhere between these two extremes.

Was the House of Lords Acting unconstitutionally? The Salisbury Convention, evolved in 1945 by the then leader of the opposition in the House of Lords, states that the House of Lords may amend, but not reject or wreck, a Bill contained in the government's manifesto. Lord Mackay, the opposition spokesman in the House of Lords, expressly denied breach of this convention because the manifesto only contained a pledge to introduce proportional representation for European elections but said nothing about the voting system to be adopted. The Lords were not rejecting the Bill at second reading, as happened in the War Crimes Bill, nor were they passing a wrecking amendment because it did not remove proportional representation from the Bill. The Lords, by their amendment passed on 20 October 1998, were asking the Commons to think again. What was unprecedented was that the Bill was batted back and forth between the two houses five times.

It was alleged by one peer that no Bill over the past 30 years had been amended by the same amendment more than twice. It was, of course, not the same amendment which ping-ponged five times between the houses. The rules of the game were the subject of a brief exchange between Lord Carter, the Labour Chief Whip and Viscount Cranborne, then the opposition leader in the House of Lords, when the Lords insisted on their 
amendment after its rejection by the Commons. Lord Carter put it succinctly when he said, 'They [the Commons] cannot insist on it again. They have to produce an amendment in lieu'; otherwise the Bill would be lost. The Commons did pass an amendment in lieu, namely providing for a review of the operation of the system to report to Parliament within six months. This did not satisfy their lordships because the elections would still be held under the closed system and there was no guarantee that a review which was unfavourable to this system would be implemented. The Commons tried again with a second amendment in lieu by adding a new sub-section to the first amendment, spelling out that the review must consider how the open list might affect the result of an election. This was derided as 'not even a crumb from the rich man's table' by the opposition spokesman in the Lords. The Bill was sent back again to the Commons with the hope of a substantial compromise. This was not forthcoming, but a third amendment in lieu provided a new sub-section making the Secretary of State consult 'such persons appearing to him to be interested as he thinks appropriate' before appointing members of the review body. This was done on the penultimate day of the session. A few hours later it was contemptuously dismissed by the opposition spokesman in the Lords as hardly moving us on a millimetre. The crunch came at $9 \mathrm{pm}$, when the Lords for the fifth time insisted on their amendment and rejected the Commons' amendment in lieu by 212 to 183 votes, with the result that the Bill was lost in that session.

\section{Legitimate use of delaying power?}

Was this a legitimate use of the delaying power given to the Lords by the Parliament Acts or a wholly improper abuse of power? There was a time when the view was held by the leader of the Conservative opposition in the Lords that this power could only be used in most exceptional circumstances on a matter of utmost gravity and importance (see G Ganz, 'War Crimes Act 1991 - Why no Constitutional Crisis?' [1992] 55 MLR 87, 92). The issue of open or closed lists could probably not have been so classified (Lord Callaghan thought it was a second-level issue). However, in the 1970s, a different view prevailed and the Conservative opposition in the House of Lords insisted on their amendments to the Trade Union and Labour Relations (Amendment) Bill in 1975 and the Aircraft and Shipbuilding Industries Bill in 1976. Nevertheless, Lord Richard, the recently deposed Labour leader of the House of Lords, was probably right when he said:

'The other side is going to break the understanding that has arisen over a number of years under successive governments as to the circumstances in which this House should insist upon its position.'

\section{Kaleidoscope of interests}

The issue was, however, far more complex than a simple confrontation between the elected and the unelected house, the elected house against hereditary peers or a straightforward party-political battle. There was a kaleidoscope of interests, often self-contradictory, which shifted as the conflict reached its climax. Paradoxically, the Conservative party had nothing to gain from defeating the Bill as they, as well as the Liberal Democrats, were bound to win more euro-seats under a system of proportional representation. Some of the inveterate Labour opponents of the Bill had axes to grind such as being euro- sceptics and/or against proportional representation. This was not, however, true of others who defied their parties on some votes against the Bill but were strongly pro-European and in favour of proportional representation. Conversely, some peers who supported the government confessed to being opposed to proportional representation. A number of peers spoke of how they changed sides as the conflict with the Commons escalated and they were afraid both of losing the Bill and of frustrating the will of the elected house. Earl Russell, a leading Liberal Democrat, illustrated these conflicting pressures most poignantly when, on the third occasion that the House of Lords voted against the government, he said he changed his mind five times before finally deciding to vote against the government once more. On the fourth occasion he did not vote, but on the fifth and last occasion, confronted with the choice, as he saw it, of killing the Bill or giving in to the government, he ended with the words of Lord Hailsham in a similar situation - 'Let them have their silly way' - and voted with the government.

Peers were not alone in wrestling with their consciences; there was much opposition to closed lists among Labour MPs, and their speeches were gleefully quoted by Lord Mackay in the next debate in the House of Lords. He especially relished the remark of one Labour MP who thought it doubtful 'that a majority of the parliamentary Labour party is in favour of the closed-list system'. His opposition to the closed list system, however, conflicted with his belief that the vicws of the elected chamber must prevail. $\mathrm{He}$ salved his conscience by abstaining, but cheerfully predicted that the government would get a majority whatever the private view of the majority of his colleagues. In the vote the government had a majority of 182 . The moral of the tale was drawn by another Labour MP, Dr John Marek, who admitted that he would be dragooned through the government lobby:

'What legitimacy does the elected chamber have in comparison with the unelected chamber whose members may, by and large, vote according to their own judgment on the right course of action for the country?'

\section{Crucial role of cross-benchers}

This statement is particularly true of the cross-benchers in the House of Lords, who do not take a party whip and who played such a crucial role in the votes on this Bill. Much play was made by the government of the number of hereditary peers who voted on each occasion and that the opposition won the votes because of the hereditary peers. This claim leaves out of account the role of the cross-benchers, the majority of whom are hereditary peers. Lord Alton asserted that without the votes of crossbenchers the government would have achieved their business on every occasion. There was, however, a revealing remark by Lord Mackay on the fifth round in the House of Lords, when he agreed with the minister that he was thinking, ' ... there are some people here I have never seen before and [was] wondering who they were'. This is an obvious reference to the 'backwoodsmen' who had been summoned by the opposition to support them in the lobbies.

With hindsight it is possible to pick up clues in this last debate about the tensions within the Conservative party which were the backdrop against which this debate was held. Lord Garel-Jones refused to speculate in public about 'the motives of the Shadow Cabinet in inviting us to vote against the Government yet again'. Even more significantly, the then leader of the opposition in the 
Lords commented immediately after the vote in which the government was defeated:

'We are aware of the limitations on the rights of this House ... and I hope that we will behave accordingly when the Bill is reintroduced.'

Two weeks later Viscount Cranborne was dramatically sacked by the leader of the opposition, William Hague, for making a deal with the government behind Mr Hague's back which would have allowed 91 hereditary peers to be reprieved temporarily in return for opposition peers not obstructing the Bill announced in the Queen's Speech to abolish the right of hereditary peers to sit in the Lords. These events foreshadowed the arrangements for the subsequent passage of the European Parliamentary Elections Bill through the Lords, but, first, the Bill had to pass through the Commons again in accordance with the procedure under the Parliament Acts.

\section{USE OF THE PARLIAMENT ACTS}

By the time the Bill returned to the Commons in the new session, the year which has to elapse between the first and last occasions it is passed in the House of Commons, had already expired. The government put before the House a guillotine motion which was alleged to be the most severe that had ever been introduced. It allowed only four hours to debate the motion and all stages of the Bill. Half of the available time was spent debating the guillotine motion and the rest on the second reading debate, so no amendments could be discussed. To comply with the Parliament Acts, the Bill which is reintroduced must be the same as the former Bill except for amendments agreed between the two houses. Because of this provision the proposal for a review of the closed list system, which was rejected by the Lords, was not included in the Bill on the second occasion. Therc was, however, a change in the explanatory memorandum, because, since the passage of the Human Rights Act 1998, the minister in charge of the Bill had to state whether the Bill complied with that Act. It was alleged by the opposition in the debate that the Bill was arguably in breach of art. 3 of the First Protocol of the European Convention on Human Rights, which provides for the holding of free elections. This can only be decided by a court.

Contrary to dire prophecies as to what would happen to the Bill in the Lords, another deal was agreed between the Conservative peers and the government about the timetable for the Bill, so that it could become law in January in time for the European Parliamentary elections to be held in June under the new system. Instead of giving the Bill a second reading and then having a protracted committee stage, the opposition put down a reasoned amendment declining to give the Bill a second reading because it included an undemocratic closed list system for which there was no mandate at the general election. Paradoxically, the passing of this amendment would help the government by speeding up the passage of the Bill which could become law under the Parliament Acts after its rejection for the second time by the House of Lords. Therefore, a vote for the amendment was in reality a vote for the Bill. The only way out of this dilemma was to abstain and this was the route taken by two inveterate opponents of the closed list system, one of whom nevertheless wanted the Bill to become law and the other of whom did not. One peer abstained because he headed one of the lists as prospective Conservative candidate. As he put it succinctly:

'To vote for the Government is promoting my candidature and, in the particular and peculiar circumstances of this evening, to vote for the amendment has the same effect.'

Others who spoke passionately in favour of the Bill abstained, but most speakers, in spite of the paradox, voted for the second reading if they supported the Bill or for the amendment if they opposed it. The 'serried ranks of the Conservative Benches' carried the day by 167 to 73 , and the Bill was returned to the Commons to be prepared for the Royal Assent. Lord Strathclyde, the new leader of the Conservative peers, taunted the government with having suffered 'an unprecedented humiliation' - no doubt with tongue in cheek. But neither was the defeat 'the death rattle of the ancien régime'. Some hereditary peers were likely to be reprieved to fight another day.

\section{CONCLUSION}

Is it a tale told by an idiot, full of sound and fury, signifying nothing? Why did the unprecedented game of ping-pong with the Lords yield no results at all? On two previous confrontations earlier in the session the Lords had won notable victories: on tuition fees for English students at Scottish universities the government promised an independent review, which was accepted by the Lords; in the case of lowering the age of consent for homosexuals to 16, the Lords' defeat of the clause, which had been added to the Crime and Disorder Bill on a free vote in the Commons, led to the withdrawal of the clause by the government with a promise of new legislation in the next session (which was again defeated in the Lords). In each case there were special circumstances leading to a deal or climbdown. The two houses when in conflict are engaged in a game of poker with each side trying to bluff the other into climbing down. n the internet

The full text of the European Parliamentary Elections Act 1999 can be found on the above website.
With hindsight the unprecedented confrontation over the European Parliamentary Elections Bill cannot be seen in isolation from the battle over House of Lords' reform which was going on behind the scenes. We now know there were divisions in the Conservative Party over how to handle this issue and that the leadership was opposed to a deal and determined to face down the government. The suspicion cannot be avoided that this was a dress rehearsal for the coming battle over Lords reform so far as the Conservative peers were concerned. Having forced the government to use the Parliament Acts, the government was then handed the Bill on a plate, as a result of a deal negotiated with the Conservative peers which cannot be divorced from the proposal to reprieve 91 hereditary members of the House of Lords.

As we have seen, however, opposition to the Bill was not just a party political battle but received support across the political spectrum and from cross-benchers and bishops. There was much heart-searching among these peers about frustrating the will of the elected house, particularly when the confrontation between the houses was reaching its climax,. It was the Earl of 
Onslow, ready to act as a football hooligan to further Lords' reform, who pointed the moral when he said:

'... this is a perfect example of why this House should be properly reformed. When it is properly reformed, we can use the powers that we have with legitimacy and pride rather than be blackmailed because we are told that we are all idiots of hereditary Peers.'

The Bill to abolish the right of hereditary peers to be members of the House of Lords was introduced in the House of Commons on 19 January. In a statement to both houses, the government confirmed that it was minded to accept an amendment to the Bill, when it reached the Lords, to temporarily reprieve some hereditary peers until there is a fully reformed second chamber. That depended, however, 'on the extent to which the normal conventions relating to the government's legislative programme are being observed' - a euphemism for not blocking the Bill. (This amendment to reprieve 92 hereditary peers has now been passed in the Lords.) The statement accompanied a White Paper setting out the government's proposals for Lords' reform both in the short term (the transitional house) and longer-term reform, which would be considered by a Royal Commission to report by the end of 1999 on the role, function and composition of a second chamber. The terms of reference make it clear that the House of Commons must remain the pre-eminent chamber of Parliament. Ominously, the government, in setting out its own views on the powers of a reformed second chamber, considers that they should be reduced, rather than restricting their exercise by 'institutionalising the understandings' under which the house now operates - understandings which were evolved precisely because the house was unreformed. In other words the government does not envisage that a second chamber endowed with greater legitimacy should act as a better check on the Commons. The Commons will still normally be dominated by the government formed from the party with a majority of MPs, unless there is electoral reform more radical than that proposed by the Jenkins Commission. Plus ça change, plus c'est la même chose. (ㄷ)

Professor Gabriele Ganz

Faculty of Law, Southampton University

\title{
Misplaced trust?
}

\author{
by Peter Willoughby
}

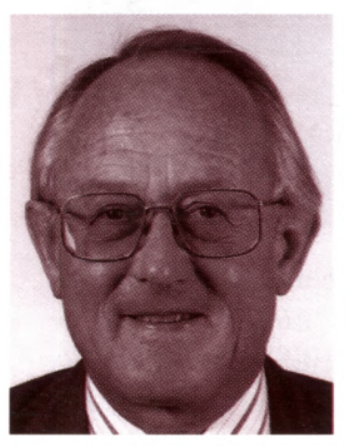

Peter Willoughby

The trust concept has been used for more than 800 years as a mechanism to protect and conserve family wealth. However, in recent years, failure to set up trusts correctly and to administer them scrupulously has resulted in litigation. Professor Peter Willoughby outlines the dangers and pitfalls of setting up and administering trusts.

$\mathrm{O}$ ver the last 30 years there has been widespread and increasing use of trusts as a way of holding personal wealth. The trust concept is one with more than 800 years of development, originally in England but more recently in many other jurisdictions. Trusts have been created for many reasons but generally the overriding need is the protection and conservation of family wealth. One of the most important advantages of a trust is that it provides a convenient and flexible way of ensuring that the benefit of assets is enjoyed by members of a family through more than one generation, without the inconvenience, publicity and expense that can occur where it is necessary to obtain a grant of probate or letters of administration or the equivalent, in several jurisdictions, on the death of a wealthy person. It may be that other advantages can be obtained, such as the mitigation of tax liabilities and the sheltering of family assets from potential creditors.

Unfortunately in more recent times trusts have all too frequently been marketed as 'products' by banks, accountancy firms and even lawyers, without proper attention to the essential legal requirements of a valid trust. In many instances, aggressive marketing by people who have not understood the need to set up trusts correctly and then to administer them scrupulously has resulted in litigation which is often multi-jurisdictional and very expensive. The practical implications of matters such as heirship and creditors' rights, together with the dangers of retaining direct or indirect control in the person creating the trust, have been underestimated. This has resulted in challenges by creditors, disinherited heirs, former spouses and revenuc authorities. 